\title{
The Effect of Cooperative Learning Model of STAD to the Mathematics Understanding
}

\author{
Deiby Tiwow*, Santje Salajang, Wayan Damai \\ Master Program in Mathematics Education \\ Universitas Negeri Manado \\ Tomohon, Indonesia \\ *dtiwow@unikadelasalle.ac.id, samsalajang@gmail.com, iwayandamai@unima.ac.id
}

\begin{abstract}
This study aims to explore the differences in math understanding of students taught using Student Achievement Divisions (STAD) and classical learning models and the student interest to mathematics learning on using cooperative learning with STAD and classical models. This research method includes the type of quasi-experimental research using Treatment by level design. Based on the results of data analysis it can be concluded that learning math with cooperative model with STAD implied to the enhancement of math understanding, better than using classical model. Learning with cooperative and STAD model give the positive impact to the interest on mathematics.
\end{abstract}

\section{Keywords: influence, STAD, results and interest in learning}

\section{INTRODUCTION}

Mathematics is one of a fundamental subject that plays an important role at every level of formal education. The study on the 2013 curriculum implies that mathematics curriculum is developed based on character and competence and should be implemented based on the needs and characteristics of the students as well as the basic capabilities in general. An educator must be able to create basic decisions based on appropriate assessments, by mastering the learning principle. Moreover, teacher to support the maximum learning achievement. Teacher should always be professional, specifically in the selection of learning models that can be able to engage students in building collaborations between students as well as create enthusiasm in learning.

This is in line with the case study conducted by Zamri [1], free translation in cooperative learning can run effectively but also requires the knowledge and skills by the educator. Cooperative learning emphasizes the collaborative activities of students in group learning by discovering subject matters and collectively solving problems in a collaborative manner [1].

Parallel to the statement by Sangeeta and Effandi, the free translation of the cooperative learning model type, "Student Achievement Divisions" (STAD), is effective compared to direct conventional models [2,3]. This learning model can stimulate student's awareness in learning and encouraging students in improving understanding on a variety of abilities and will ensure the student's success in mastering the material. Awareness and encouragement are what gives a big influence in providing achievement support in learning $[1,4]$.
According to Priansa [5], a desire will be accompanied by attention and activeness eventually gives birth to a sense of pleasure in behavior changes including knowledge, attitude, and skills provides an understanding of interest in learning. Judging from the results of temporary observations at one of the junior high school in Manado, the selection of the model by the educator was incorrect.

The learning process still uses a contextual learning model that is direct learning, the attention of students in participating in teaching and learning activities is mostly based on the student's fear of the educator, some students' lack of interest comes from less book reading and most students are less interested in following this learning process concluding that there are still many students uses their cellular phones and engages in small talks during class. This also affects the understanding of students who have not met basic level. This study aims to answer the research questions as follows:

- How is the math understanding of students who are involve in the math learning using cooperative-STAD model, compare to the classical model?

- What is the effect of cooperative-STAD model of learning to the student interest toward math?

\section{RESEARCH METHODS}

The method used in this study was an experimental method with the design "Treatment by Level" $2 \times 2$. The intended design can be illustrated in the matrix presented in table 1 .

\section{TABLE I. RESEARCH DESIGN}

\begin{tabular}{|l|l|l|}
\hline \multirow{2}{*}{\multicolumn{1}{c|}{ B }} & \multicolumn{3}{|c|}{ A } \\
\cline { 2 - 4 } & \multicolumn{1}{|c|}{$\boldsymbol{A}_{\mathbf{1}}$} & $\boldsymbol{A}_{\mathbf{2}}$ \\
\hline $\mathrm{B}_{1}$ & $\mathrm{Y}_{11}$ & $\mathrm{Y}_{21}$ \\
\hline $\mathrm{B}_{2}$ & $\mathrm{Y}_{12}$ & $\mathrm{Y}_{22}$ \\
\hline
\end{tabular}

Description:

\section{A : Cooperative Learning Model}

$\mathbf{A}_{1}$ : Student groups that are given

STAD learning 
The complete description of the math understanding of student in each group:

Conventional learning

B : Learning Interest

$\mathrm{B}_{1}$ : Student groups with high interest in learning.

$\mathrm{B}_{2}$ : Student groups with low interest in learning.

Y : Understanding.

\section{RESULTS AND DISCUSSION}

From the research results obtained, the data of interest in learning is then compiled using a sequence ranking technique. Furthermore, $30 \%$ of students who have the highest scores and $30 \%$ of students who have the lowest scores are taken. This $30 \%$ is adjusted in Nitko's opinion [4] to determine the upper and lower groups, with $25 \%$ to $33 \%$ of range can be used. For more details, the composition of research subjects based on the group of data interests can be presented in the table 2 .

TABLE II. STUDENT UNDERSTANDING DATA

\begin{tabular}{|c|c|c|c|c|c|c|c|c|}
\hline Group & $\mathbf{N}$ & $\begin{array}{c}\text { Score } \\
\text { Min }\end{array}$ & $\begin{array}{c}\text { Score } \\
\text { Max }\end{array}$ & $\begin{array}{c}\text { Mean } \\
(\mathbf{X})\end{array}$ & $\begin{array}{c}\text { Modus } \\
(\mathbf{M o})\end{array}$ & $\begin{array}{c}\text { Median } \\
(\mathbf{M e})\end{array}$ & $\begin{array}{c}\text { St. } \\
\text { Deviatio } \\
\mathbf{n}\end{array}$ & $\begin{array}{c}\text { Variants } \\
(\mathbf{S 2})\end{array}$ \\
\hline $\mathrm{A} 1$ & 10 & 75 & 94 & 84.3 & 91 & 84 & 8.02 & 64.45 \\
\hline $\mathrm{A} 2$ & 10 & 36 & 75 & 55.9 & - & 54 & 16.65 & 277.43 \\
\hline B1 & 10 & 64 & 95 & 81.5 & 91 & 82.5 & 11.13 & 124 \\
\hline B2 & 10 & 78 & 36 & 58.6 & 78 & 59 & 19.288 & 372 \\
\hline A1B1 & 5 & 90 & 94 & 91.8 & 91 & 91 & 1.64 & 2.7 \\
\hline A1B2 & 5 & 75 & 78 & 76.8 & 78 & 77 & 1.3 & 1.7 \\
\hline A2B1 & 5 & 65 & 75 & 71.4 & - & 73 & 4.03 & 16.3 \\
\hline A2B2 & 5 & 36 & 43 & 40.4 & - & 41 & 2.7 & 7.3 \\
\hline
\end{tabular}

\section{Description:}

$\mathrm{A}_{1} \quad$ : Scores from experimental group who were given STAD learning.

$\mathrm{A}_{2} \quad$ : Scores from control group who were given classical learning.

$\mathrm{B}_{1} \quad$ : Scores from group of students with high interest in learning mathematics.

$\mathrm{B}_{2} \quad$ : Scores from groups of students with low interest in learning mathematics.

$A_{1} B_{1}$ : Scores from groups of students who were given STAD learning and have a high interest in learning mathematics.

$A_{1} B_{2}$ : Scores from groups of students who were given STAD learning and have a low interest in learning mathematics.

$A_{2} B_{1}$ : Scores from groups of students who are given conventional learning and have a high interest in learning mathematics.

$A_{2} B_{2}$ : Scores from groups of students who are given conventional learning and have a low interest in learning mathematics

\section{A. Mathematics understanding from groups of students who were given $S T A D$ learning $\left(A_{1}\right)$}

In this group, the scores of 10 students are in the $75-94$ range with an average score of 84.3 , median $=84$, mode $=91$, standard deviations $=8.02$ and variance $=64.45$. Theoretically, the score should be in the 36-94 range with an average score of 70.1 The empirical mean obtained is 84.3 . If the empirical value is compared with the theoretical value, then this empirical result can be categorized as having a high score. Therefore, it can be concluded that the score of mathematics understanding in the class taught with the STAD type learning model is relatively high.

\section{B. Mathematics understanding from groups of students who were given conventional learning $\left(A_{2}\right)$}

In this group, the scores of mathematics understanding of 10 students are in the range of 75 -36 with an average score of 55.9 , median $=54$, standard deviations $=16.65$ and variance $=$ 277.43. Theoretically, the score of students' mathematics understanding should be in the 36-94 range with an average score of 70.1. The empirical mean obtained is 55.9 If the empirical value is compared with the theoretical value, then this empirical result can be categorized as having a low score. Therefore, it can be concluded that the score of mathematics understanding in the class taught with conventional type learning models is relatively low.

\section{Mathematics understanding from groups of students with higher interest in learning mathematics $\left(B_{1)}\right.$}

In this group, the scores of math understanding of 10 students is in the 94-64 range with an average score of 81.5, median $=82.5$, mode $=91$, standard deviations $=11.13$ and variance $=124$. Theoretically, the learning outcome score Mathematics students should be in the 36-94 range with an average score $=70.1$ The empirical mean is 81.5. If the empirical value is compared with the theoretical value, then this empirical result can be categorized as having a high score. Therefore, it can be concluded that the score of understanding in mathematics in the class who have high interest, is relatively high.

\section{Mathematics understanding from groups of students with low interest in learning mathematics $\left(B_{2}\right)$}

In this group, the scores of 10 students are in the $78-36$ range with an average score of 58.6, median $=59$, mode $=78$, standard deviations $=19.28$ and variance $=372$. Theoretically, the score should be in the range 36-94 with an average score $=$ 70.1 The empirical mean obtained is 58.6. If the empirical value is compared with the theoretical value, then this empirical result can be categorized as having a low score. Therefore, it can be concluded that the mathematics as low. understanding in the class who have low interest is classified 
learning models that have low learning interest, are classified as low.

1) Prerequisite test (normality). The Normality data test uses Kolmogorof-Smirnov with the help of SPSS. Based on the SPSS output table, it is known that the value of sig. is $0.248>0.05$. Therefore, it can be concluded that the data are normally distributed.

2) Homogeneity. Based on the test results obtained, the sig. variable of the understanding from class VIII-A and class VIII-B is equal to $0.706>0.05$. As the basis for decision making in the homogeneity test it is concluded that the data variance of mathematics understanding for students in class VIII-A and class VII-B are the same or homogeneous.

3) Hypothesis test. The table 3 contains the summary of ANOVA-2 directions using the SPSS application.

\section{F. Mathematics understanding from groups of students who were given STAD learning and have a low interest in learning mathematics $\left(A_{1} B_{2}\right)$}

In this group, the score of 5 students is in the $78-75$ range with an average score of 76.8 , median $=77$, mode $=78$, standard deviation $=1.3$ and variance $=1.7$. Theoretically, the score should be in the 36-94 range with an average score 70.1 and the empirical mean obtained is 76.8 . If the empirical value is compared with the theoretical value, then this empirical result can be categorized as having a high score. Thus it can be concluded that the score of mathematics understanding in the class taught with the STAD type learning model that has low learning interest is classified as high.

G. Mathematics understanding from groups of students who are given conventional learning and have a high interest in learning mathematics $\left(A_{2} B_{1}\right)$

In this group, the score of 5 students is in the 75 - 65 range with an average score of 71.4 , median $=73$, standard deviations $=4.03$ and variance $=16.3$. Theoretically, the score should be in the 36-94 range with an average score of 70.1 and the empirical mean obtained is 71.4 . If the empirical value is compared with the theoretical value, then this empirical result can be categorized as having a high score. Thus it can be concluded that the mathematics understanding in the class taught with conventional learning models that have high learning interest, are classified as high.

\section{H. Mathematics understanding from groups of students who} are given conventional learning and have a low interest in learning mathematics $\left(A_{2} B_{2}\right)$

In this group, the score of mathematics understanding of 5 students is in the 43-36 range with an average score of 40.4, median $=41$, standard deviations $=2.7$ and variance $=7.3$. Theoretically, the score of students' mathematics understanding will be in the 36-94 range with an average score of 70.1 and the empirical mean obtained is 40.4. If the empirical value is compared with the theoretical value, then this empirical result can be categorized as having a low score. Thus it can be concluded that the scores of mathematics understanding in class that are taught with conventional
TABLE III. TEST OF BETWEEN-SUBJECTS EFFECTS

\begin{tabular}{|c|c|c|c|c|c|}
\hline Source & $\begin{array}{l}\text { Type III } \\
\text { Sum of } \\
\text { Squares }\end{array}$ & df & $\begin{array}{l}\text { Mean } \\
\text { Square }\end{array}$ & $\mathbf{F}$ & Siq \\
\hline $\begin{array}{l}\text { Corrected Model } \\
\text { Intercept }\end{array}$ & 6995.350 & 3 & 2331.783 & 346.734 & .000 \\
\hline Model & $\begin{array}{l}98140.050 \\
4061.250\end{array}$ & 1 & $\begin{array}{l}98140.050 \\
4061.250\end{array}$ & $\begin{array}{l}1.459 \mathrm{E} 4 \\
603.903\end{array}$ & $\begin{array}{l}.000 \\
.000\end{array}$ \\
\hline Interest & 2622.050 & 1 & 2622.050 & 389.896 & .000 \\
\hline Model"interest & & 1 & 312.050 & & \\
\hline Error & 107.600 & 16 & 6.725 & & \\
\hline Total & 105243.000 & 20 & & & \\
\hline Corrected Total & 7102.950 & 19 & & & \\
\hline
\end{tabular}

4) Hypothesis I. From the ANOVA-2 direction summary table the data obtained is $\mathrm{F}_{\text {calculated }}=603.903$ (>3.63) while $\mathrm{H} 0$ is rejected and $\mathrm{H} 1$ is accepted, hence, it can be concluded that there is a significant difference between understanding in groups of students who are taught using STAD type cooperative learning models and conventional learning models.

5) Hypothesis II, Based on the ANOVA-2 summary table, the price obtained is $\mathrm{F}_{\text {calculated }}=389.896(>3.63)$ while $\mathrm{HO}$ is rejected and $\mathrm{H} 1$ is accepted, hence, it can be concluded that there is a significant interaction between the learning model of student understanding if viewed from the learning interest.

6) Advanced testing. The hypothesis of the differences in understanding taught by the STAD type cooperative learning model and conventional learning models for students who have high learning interest.

Test Criteria:

Decline $\mathrm{H}_{0}$ (accepts $\mathrm{H}_{1}$ ), if $\mathrm{Q}_{\text {calculated }}>\mathrm{Q}_{\text {table }}$

Decline $\mathrm{H}_{1}$ (accepts $\mathrm{H}_{0}$ ), if $\mathrm{Q}_{\text {calculated }}<\mathrm{Q}_{\text {table }}$ 
[5], about the effectiveness of cooperative learning models in terms of student's achievement and learning interests.

\section{CONCLUSION}

By the research, it can be concluded that the cooperativeSTAD model of learning can enhance the mathematics understanding of student, higher than in the classical class.it is also found that the interactive models of learning show the positive impact to the math understanding. In the higher and lower levels of student interest, the achievement of student is higher than in the classical one with the same interest level.

\section{REFERENCES} the models of learning (cooperative-STAD and classical learning) is as follows.

Decline $\mathrm{H}_{0}$ (accepts $\mathrm{H}_{1}$ ), if $\mathrm{Q}_{\text {calculated }}>\mathrm{Q}_{\text {table }}$

Decline $\mathrm{H}_{1}$ (accepts $\left.\mathrm{H}_{0}\right)$, if $\mathrm{Q}_{\text {calculated }}<\mathrm{Q}_{\text {table }}$

The value of $\mathrm{Q}_{\text {table }}=5.79$

The value of $Q_{\text {calculated }}$ is:

$$
\text { Qcalc }=\frac{\overline{\mid Y_{11}}-\overline{Y_{12} \mid} \mid}{\sqrt{\frac{R J K_{D}}{n}}}=\frac{|76.8-40.4|}{\sqrt{\frac{6.72}{4}}}=\frac{36.4}{\sqrt{\frac{6.72}{4}}}=\frac{36.4}{1.29}=28.21
$$

Because $\mathrm{Q}_{\text {calculated }}=28.21(>5.79) \mathrm{H} 1$ is accepted. This shows that "Mathematics understanding using the STAD modelin the experimental group are higher than the control group who have low learning interest". The description and discussion of the above research results are relevant with Huta
[1] Z. Mahamod, B. Somasundram "Effectiveness of Cooperative Learning on the Achievement and Motivation of Student in Learning Malay Languange". Vol 2017. Creative Education. 2017.

[2] S Yaduvanshi, S Singh "Fostering Achievement of Low Average, and High Achievers Students in Biology through Strudctured Cooperative Learning (STAD Method"). Vol 2019. Education Research International. 2018.

[3] Z. Effandi, Zakaria, "Effect of Cooperative Leaning on Seconfary Research. 2013.

[4] M. Huta, Model-model Pengajaran dan Pembelajaran. Yogyakarta: Pustaka Pelajar. 2017.

[5] D. Priansa, Pengembangan Strategi \& Model Pembelajaran. Bandung: Pustaka Setia. 2017. School Students Mathematics Achievement". Vol 2013: Scentific 